BNWL-1853

Special

Distribution

\title{
PACIFIC NORTHWEST LABORATORY MONTHLY ACTIVITIES REPORT JULY 1974
}

Division of Production and Materials Management and Hanford Plant Assistance Programs

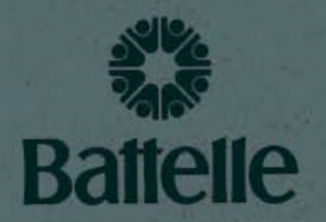

Pacific Northwest Laboratories

Richland, Washington 99352

AUGUST 1974

Prepared for the U.S. Atomic Energy Commission under Contract AT(45-1):1830 
NOTICE

The report was prepared as an account of work sponsored by the United States Government. Neither the United States nor the United States Atomic Energy Commission, nor any of their employees, nor any of their contractors, subcontractors, or their employees, makes any warranty, express or implied, or assumes any legal liability or responsibility for the accuracy, completeness or usefulness of any information, apparatus, product or process disclosed, or represents that its use would not infringe privately owned rights.

\title{
PACIFIC NORTHWEST LABORATORY \\ operated by \\ BATTELLE \\ for the \\ U.S. ATOMIC ENERGY COMMISSION \\ Under Contract AT(45-1)-1830
}

\author{
Printed in the United States of America \\ Available from \\ National Technical Information Service \\ U.S. Department of Commerce \\ 5285 Port Royal Road \\ Springfield, Virginia 22151
}

Price: Printed Copy \$4.00; Microfiche \$1.45 
BNWL -1853

(Special Distribution)

\section{PACIFIC NORTHWEST LABORATORY}

MONTHLY ACTIVITIES REPORT

JULY 1974
Division of Production and Materials Management and
Hanford Plant Assistance
Programs

by the

Staff of Battelle-Northwest

E. L. Alpen, Director

August 1974

BATTELLE

PACIFIC NORTHWEST LABORATORY

RICHLAND, WASHINGTON 99352 


\section{TABLE OF CONTENTS}

\section{Page}

Assistance to Atlantic Richfield Hanford Company - Summary. . . . . 3

Assistance to Atlantic Richfield Hanford Company. . . . . . . . . . 6

Technical Assistance to the Hanford Plant - Summary . . . . . . 16

Technical Assistance to the Hanford Plant . . . . . . . . . 17 
BNWL -1853

\author{
PACIFIC NORTHWEST LABORATORY \\ MONTHLY ACTIVITIES REPORT \\ DIVISION OF PRODUCTION AND MATERIALS MANAGEMENT \\ AND HANFORD PLANT ASSISTANCE PROGRAMS \\ ASSISTANCE TO ATLANTIC RICHFIELD HANFORD COMPANY
}

Summary

PROCESS TECHNOLOGY - DEVELOPMENT ENGINEERING DEPARTMENT

Storage of High-Leve1 Liquid Wastes

In horizontal wiped-film evaporator studies, the water content of a simulated crystallizer slurry was reduced from an initial $43 \mathrm{wt} \%$ to $26 \mathrm{wt} \%$. The concentrated product was highly fluid as it discharged from the evaporator $\left(167^{\circ} \mathrm{C}\right)$; it solidified on cooling. Overall heat transfer coefficients of about $250 \mathrm{BTU} / \mathrm{hr}-{ }^{\circ} \mathrm{F}-\mathrm{ft}^{2}$ were observed.

A final design has been established for the electronics portion of the "point probe" inspection system. Fabrication of the prototype electronics package is currently underway.

Tests are in progress to determine the suitability of 304L stainless steel as an anode material exposed to alkaline high-level solidified waste. Other tests have been initiated to determine current distribution in a cathodically protected mild steel tank as a function of anode placement.

The response of Corrator and Corrosometer-type probes suitable for exposure in underground waste tanks was evaluated and found to be satisfactory.

A final report on the engineering audit of the FIC System has been written and will be issued soon. Issuance of the final report will conclude this program.

The breadboard ultrasonic logging system is nearly complete. Final laboratory testing is underway, and installation can begin when installation of the "wet wells" in Tank $111 \mathrm{~s}$ is complete. 
Testing was initiated on a field installed prototype system for detecting tank leaks based on changes in the electrical resistivity of soil. Initial results offer promise that the system can improve present leak detection capabilities.

Test equipment was installed in a waste tank farm for detecting waste tank leaks based on changes in soil impedance. Testing was started.

\section{PROCESS TECHNOLOGY - RESEARCH DEPARTMENT}

Soi1 Characteristics in $\mathrm{Z}$ Trenches

The stored sediment cores from the 216-Z1A tile field and 216-Z-9 covered trench were plastic impregnated, mounted and polished, and are now being autoradiographed.

Examination of altered rock fragment areas in the 216-Z1A sediments show them to be depleted in aluminum, potassium, magnesium, calcium, and iron in relation to the original rock fragment chemical composition.

\section{Plutonium Scrap Processing Development}

Further tests of the fused $\mathrm{NaOH}-\mathrm{Na}_{2} \mathrm{O}_{2}$ technique for solubilizing refractory $\mathrm{PuO}_{2}$ in process wastes were made on centrifuge sludge from the plutonium reclamation facility. Good recovery of Pu was attained.

Tank Farm Support

Nineteen selected sediment samples from $S$ and T Tank Farms (200 West Area) have been characterized in the laboratory.

Prevention of Accidental Releases

- Surficial Contamination and Airborne Release

Experiments to measure airborne release of $\mathrm{Cs}-137$ and $\mathrm{Sr}-90$ during the heating of contaminated surface materials continued.

Airborne material resuspension patterns from the $B-C$ crib area, as determined by computer modeling and actual contamination contours, was found to correspond quite closely to the surface distribution. 
Mass fractions of surface materials and size distribution of soil (by sieving) have been determined for samples collected from the overflow ditch and bank of $Z$ ditch.

Airborne radionuclides were determined at $U$-pond as a function of airborne particle dianeter and attachment to airborne soil.

Concentrations of $\mathrm{SF}_{6}$ were determined for aircraft samples taken during two early morning releases and stability conditions were determined for use in diffusion modeling work. Visual simulation of wind trajectories through computer programs continues to appear a promising way to display the motion of particles from a source.

Observing and photographing of dust devils were undertaken at two locations on the project area. The report being prepared on dust devils will be delayed until summer observations and reports can be incorporated.

\section{- Groundwater Management Studies}

All data from well logs have been transferred to magnetic tape storage.

Seven program planning documents were completed covering Battelle research related to ARHCO programs. The quarterly water level measurements of the Hanford Reservation wells was completed during July.

Four topical reports were drafted during the past month.

The quarterly tape run for water level measurements was completed.

The bi-monthly moisture content measurements were made in the lysimeters.

A topical report of the initial work with B-Plant condensate waste and soil is being prepared.

A topical report documenting the present 1 imitations and assumptions on the PERCOL model was prepared. 


\section{ASSISTANCE TO ATLANTIC RICHFIELD HANFORD COMPANY}

\section{PROCESS TECHNOLOGY - DEVELOPMENT ENGINEERING DEPARTMENT}

\section{Storage of High Level Liquid Waste}

- Waste Characterization

Wiped-Film Evaporator Studies

(R. D. Dierks, Process Demonstration Section)

Two experiments with the wiped-film evaporator were conducted during July in which the feed was a crystallizer slurry containing 43 wt\% water. During both experiments the evaporator paddles were rotated at 450 RPM and were adjusted to maintain a 1/32-inch thick film of material on the heat exchanger. The slurry was fed to the evaporator at $123^{\circ} \mathrm{C}$, just under its initial boiling point of $125^{\circ} \mathrm{C}$. Feed rate was maintained constant at $30 \mathrm{l} / \mathrm{hr}$ in one run and $60 \mathrm{l} / \mathrm{hr}$ in the other while the jacket steam pressure was varied in discrete increments from 50 to 116 psig.

At the maximum steam pressure available (116 psig) the evaporator discharged a 1 iquid product with a water content of $25.7 \mathrm{wt} \%$ at a feed rate of $30 \mathrm{l} / \mathrm{hr}$ and $29.1 \mathrm{wt} \%$ at a feed rate of $60 \mathrm{l} / \mathrm{hr}$; both products solidified on cooling.

With $\Delta T$ calculated simply as the arithmetic mean difference between the steam jacket temperature and the discharge and inlet end liquid temperatures within the evaporator (instead of the discharge end and the preheated feed temperatures), overall heat transfer coefficients of about $250 \mathrm{BTU} / \mathrm{hr}-{ }^{\circ} \mathrm{F}-\mathrm{ft}^{2}$ were realized. They were essentially independent of product composition or feed rate.

\section{- $\quad$ Tank Integrity}

U1trasonic Detection of Stress Cracks in Tanks

(G. J. Posakony, Nondestructive Testing Section)

A final design has been established for the electronics portion of the field prototype "point probe" inspection system. Fabrication of the electronic circuitry is currently underway. The electronics package will provide a visual indication of the test signal via a front panel meter and will also 
provide a D.C. signal output for making permanent records (strip chart recordings) if desired. The system is designed to operate on standard 110 VAC power, and the entire electronics system is being placed in a small (approximately $9 \times 7 \times 11$ in.) portable instrument cabinet. Final assembly and checkout of the electronics will begin shortly.

Corrosion Studies

(R. F. Maness, Corrosion Research and Engineering Section)

Tests are in progress to determine the suitability of $304 \mathrm{~L}$ stainless steel as the anode material in an underground tank cathodic protection system. In these tests mild steel containers partially filled with simulated solidified high-level waste at $60^{\circ} \mathrm{C}$ act as cathodes while $1 / 8 \mathrm{in}$. diameter $304 \mathrm{~L}$ rods act as anodes. Three current densities are being used; 25, 50, and $100 \mathrm{amp} / \mathrm{ft}^{2}$. The condition of the anodes will be evaluated after one month's exposure.

A mild steel tank $2 \mathrm{ft}$ in diam. and $12 \mathrm{in.} \mathrm{high} \mathrm{has} \mathrm{been} \mathrm{obtained} \mathrm{and}$ will be used to determine current distribution as a function of anode placement. Initial studies will be made using a single stainless steel anode and dilute $\mathrm{NaOH}-\mathrm{NaNO}_{3}-\mathrm{NaNO}_{2}$ solution (specific resistance about $25 \mathrm{ohm}-\mathrm{cm}$ ). A platinized titanium anode is on order and will be evaluated in simulated solidified waste when received.

A three-electrode Corrator-type corrosion probe and a Corrosometer probe, both suitable for in-tank corrosion rate measurements, were received and their response evaluated in dilute sulfuric acid $(\mathrm{pH} 2)$. Instantaneous corrosion rates obtained with the Corrator probe agreed well with the average corrosion rate obtained with the Corrosometer probe over a $24-\mathrm{hr}$ period and with rate data obtained with coupons via weight loss.

Tests were continued in which mild steel crevice specimens were exposed to aliquots of simulated solidified waste which contained varying amounts of nitrite $(0.0,0.1,0.5,2.5,5,10$, and $15 \%)$. The waste was held at $60^{\circ} \mathrm{C}$ in polyethylene containers and contained 15\% excess water. After 2700 exposure hours the corrosion rate of all specimens was about $20 \mathrm{mils} / \mathrm{yr}$ as determined by weight loss. Ammonia was an obvious reaction product in all cases. Pitting and crevice attack appeared to be essentially independent of the nitrite content within the limits evaluated. The corrosion rates obtained were about ten-fold higher than previously obtained in tests utilizing mild steel containers as well as coupons. 


\section{- Leak Detection}

\section{Internal Measurements}

(G. J. Posakony, Nondestructive Testing Section)

A final report on the engineering audit of the FIC system was written. The report contains a brief description of the liquid level monitoring system and its various components. The engineering audit results are based on a review of system design, discussions with appropriate ARHCO personnel, review of field service records, laboratory evaluation of selected components and initial output data from a fault-tree computer analysis. Some potential problem areas are identified. Issuance of the report will complete this study.

Work on the data system interfacing necessary for in-tank tests of the RF-type liquid level measuring system involved constructing, packaging, and testing of a data collection system capable of selcting data from one of ten possible antenna systems and printing the results digitally on a selective data frame with identification of the channel.

The breadboard ultrasonic logging system is nearly complete and should be available for in-tank installation by August 1. Three ultrasonic transducers have been designed and built for placement in the "wet wells" to be installed in Tank $111 \mathrm{~s}$.

Difficulty in obtaining $1 \mathrm{in}$. diameter tubing for the wet wells resulted in choosing $1.125 \mathrm{in}$. diameter tubing having $0.095 \mathrm{in}$. wall. Some slight modifications to the transducers required to make them compatible with the increased tubing diameter are currently being made. The transducers are designed to be suspended from a graduated steel tape mounted at the upper end of the wet wells. A weight has been attached to the lower end of each transducer to increase the downward force on the steel tape. Transducer positioning will be accomplished by winding or unwinding the tape spool as necessary. 
Final laboratory tests of the entire breadboard ultrasonic logging system are underway. The entire breadboard system including the transducers, positioning mechanisms, and electronics package is being tested under simulated waste tank conditions. These tests will be completed prior to installation of the actual wet wells.

A circuit has been designed and assembled which will control the operation of a strip chart recorder in accordance with the drive voltage applied to the variable speed drive motors. This will permit semi-automatic vertical scans and data recording. The motor drive system will be incorporated into the breadboard system sometime after initial installation and testing of the manual positioning devices.

- Material Balance

(D. P. Grandquist, Safeguards Systems Section)

Work was started on determining the normal $2 \sigma$ operating limits for the 242-S Evaporator System. Additional measurement data are required to make sound error estimates; hence, the operating 1 imits can only be roughly determined based largely on engineering judgment and operating experience.

External Measurements

(E. M. Woodruff, Corrosion Research and Engineering Section and

0. H. Koski, Chemical Development Section)

A concept for improved waste tank leak detection based on electrical transmissivity changes in soil surrounding a waste tank is being investigated. The principle was successfully demonstrated under simulated conditions using an array of wells to represent waste tank geometry and permit measurement of changes occurring as fluid was introduced to the soil.

Current activities involve actual tank farm application of the system. Representatives of Boeing Aerospace Company, with the assistance of ARHCO and BNW personnel, installed and tested a leak detection system in a portion of the BX tank farm. The system permitted testing circuit isolation of individual tanks, using adjacent wells as sensing probes, and the sensitivity of measurements to water introduced to soil through a well adjacent to one of the tanks. Circuit components fabricated at Boeing performed satisfactorily in the field and provided selective tank isolation. Field 
potential circuits connecting tanks with wells in the vicinity also gave satisfactory response. Some problems in making the test were encountered and the test has not been completed. However, sufficient sensitivity was demonstrated in detecting soil conductance paths to offer considerable promise that this system can improve present leak detection capabilities and provide data for the interpretation of plume migration and geometry. Tests will be resumed after the casing in a plugged well has been pulled back to give liquid access to the soil.

Another approach to leak detection through external measurements involves determining the impedance of the soil between a waste tank and an adjacent well. The installation of test leads from adjacent wells to tanks SX110, Sx113, and SX114 permitted obtaining data on soil resistance from well to well and tanks to wells.

The resistances are typically an order of magnitude lower than observed in the tank leak simulation field tests. Capacitance values are, in general, higher than noted in the field tests.

Electrode to electrode and tank to electrode DC potentials (without applied potential) having values as high as $260 \mathrm{mV}$ were observed. The highest potentials noted were for tank $5 \times 113$, a known leaker. Analysis of the data is in progress.

\section{PROCESS TECHNOLOGY - RESEARCH DEPARTMENT}

\section{Soil Characteristics in $\mathrm{Z}$ Trenches}

Characterization of 216-Z1A Tile Field Sediments

(L. L. Ames, Water and Waste Management Section)

As reported last month, several additional cores of sediments from the 216-Z1A tile field were received in June and stored pending resuming the studies after July 1 . Work on the cores has now progressed to autoradiography of the polished samples. Eight samples from 13 to $18.25 \mathrm{ft}$ below the surface of 216-Z1A tile field and two additional samples from the 216-Z-9 covered trench comprise the samples being processed at present. 
Work on sediment sample 1-6 from 5.9 feet below the surface of the 216-Z-9 tile field yielded some interesting results on sediment alteration by silicate hydrolysis. In chemical analyses of adjoining altered and unaltered areas in the sediment rock fragments, altered areas were depleted in aluminum, potassium, magnesium, calcium, and iron in relation to unaltered areas. The largest concentrations of plutonium and americium were in the altered areas.

\section{Plutonium Scrap Processing Development}

Recovery of Plutonium from Process Wastes

(J. A. Partridge, Chemical Development Section and

E. J. Wheelwright, Applied Chemistry Section)

Five tests of the $\mathrm{NaOH}-\mathrm{Na}_{2} \mathrm{O}_{2}$ fusion technique for solubilizing refractory $\mathrm{PuO}_{2}$ in process wastes were completed using centrifuge sludge from the plutonium reclamation facility. In four tests the melts were held at $600^{\circ} \mathrm{C}$ for one hour; in one test time-at-temperature was two hours. Solubilization of plutonium when the cooled melts were dissolved in dilute $\mathrm{HNO}_{3}$ averaged over $80 \%$ in the five tests; it was essentially quantitative in the two-hour test.

Gelatinous solids remain when the cooled melts are dissolved in $\mathrm{HNO}_{3}$. Washing these solids free of the Pu-containing $\mathrm{HNO}_{3}$ solution is difficult. The solids are voluminous and, when separated by centrifugation, have a dry weight 1.2 - 2.1 times as great as the starting sludge. When the solids are fired to $800^{\circ} \mathrm{C}$ a glassy clinker is formed; composition of the clinker has not been determined.

\section{Tank Farm Support}

Hydraulic Properties of Tank Farm Sediments

(S. J. Phillips, Resources Systems Section)

Nineteen selected sediment samples from the $S$ and $T$ tank farms (200 West Area) have been characterized in the laboratory as to saturated hydraulic conductivity, saturated moisture content, bulk and particle density, capillary pressure versus saturation, capillary pressure versus relative hydraulic conductivity, and relative hydraulic conductivity versus saturation. Data obtained will be input into the data analysis and computer program. Additional sediment samples are being obtained in the T-tank farm (200 West Area) for analysis of hydraulic properties. These analyses are part of the tank farm characterization program. 


\section{Prevention of Accidental Releases}

\section{- Surficial Contamination and Airborne Release}

B-C Crib Studies

(J. Mishtma and L. C. Schwendiman, Particulate and Gaseous waste Research Section)

Potential Airborne Release of Contaminated Surface Material by Heating

Experiments to measure the fractional airborne release of Cs-137 and Sr-90 during the heating of contaminated surface materials at $400^{\circ} \mathrm{C}$ have been completed and a few experiments at $600^{\circ} \mathrm{C}$ have been performed. Weight loss from organic materials showed some increase from values measured at $200^{\circ} \mathrm{C}$. Limited data on Cs-137 airborne during these experiments indicate fractional releases remain low. An airborne release as high as six percent can be calculated using the potential activity measured in both the effluent filter and bubbler samples. A high value is questionable since the activity in almost all the filter and bubbler samples is at the lower limit of detection. Placing a thin layer of glass wool over the top of the $3.5 \times 3.5 \times 2$ in. deep stainless pan provides sufficient insulation to allow use of the apparatus at $600^{\circ} \mathrm{C}$.

Safety Analysis of B-C Crib Area Contamination

The computer subroutine which plots isopleths of air concentration has been successfully added to the computer model which calculates the airborne distribution of material resuspended from the $B-C$ crib area. It shows that the airborne patterns follow the surface distribution pattern to a closer degree than expected. In order to test this relationship, resuspension factors are also being calculated and isopleths are being drawn.

U-Pond Contamination Studies

(L. C. Schwendiman and J. Mishima, Particulate and Gaseous waste Research Section)

Surface materials (to a depth of $1 \mathrm{~cm}$ ) have been collected from seven plots along the old overflow ditch and six plots on the bank of the $z$ ditch. Collected material was segregated into three categories -- soil, live vegetation and organic litter. Soil constituted most of the mass of all samples 
(as much as $99.9+$ percent). Live vegetation represented from 0.03 to 27.3 percent of the mass collected and organic litter represented from 0 to 14.6 percent. Aliquots of the soil from all seven overflow ditches and three $Z$ ditch samples have been sieved; median mass diameters range from 0.13 to $0.24 \mathrm{~mm}$.

Resuspension from Contaminated Surfaces -- Field Studies (G. A. Sehmel, F. D. Floyd, and L. C. Schwendiman, Particulate and Gaseous Waste Research Section)

As reported previously, total airborne concentrations of $2 r-\mathrm{Nb}-95$, $\mathrm{Cs}-137, \mathrm{Be}-7$, and $\mathrm{K}-40$ at U-pond increased non-linearly as wind speed increased. Wind speed increments for air sampling were 3 to 8,8 to 13 , and $13+\mathrm{mph}$. Concentrations have now been calculated for five particle diameter ranges as determined by the $7,3.3,2.0,1.1 \mu \mathrm{m}$ and backup filter collection by cascade impactors. For individual isotopes, airborne concentration and concentration increase as a function of wind speed were nearly the same for particles collected on each of the four larger stages. For backup filter particles, airborne concentrations of $\mathrm{Zr}-\mathrm{Nb}-95, \mathrm{Cs}-137$, and Be-7 were approximately 10,2, and 4 times greater, respectively, than for any on the individual large particle sizes. In contrast, for the backup filter particles, K-40 airborne concentrations were approximately one-third of the concentration of any of the individual larger particle sizes.

Airborne radioactivity per $g$ of airborne soil collected on each stage of the cascade impactor decreased non-linearly as a function of increasing wind speed. One cause for this decrease could be that uncontaminated soil is transported to the samplers from off-site at the higher wind speeds. If so, the airborne radioactivity per $g$ of airborne soil measured at the lowest wind speeds would be more closely related to local radioactivity levels on the ground than when measured at higher wind speeds.

Wind Trajectory Studies (L. L. Wende11, W. F. Sandusky, R. N. Lee, and M. M. Orgi11, Atmospheric Physics Section)

During July the $\mathrm{SF}_{6}$ concentrations were determined for the aircraft samples taken during the two early morning releases. Details of the stability 
conditions are being determined from the tower data for use in diffusion modeling comparison work. A report was started on the regional dispersion model which has been adapted for use for the Hanford site. The model is designed to provide more realistic dispersion estimates for distances beyond $10 \mathrm{~km}$ from the source.

Attempts are continuing to overcome software development problems in the microfilm plotting equipment for directly producing motion pictures from the transport model. The capability of incorporating color into these pictures will allow the comparison of single station and wind-field transport in visually impressive fashion.

Significance of Dust Devils and Anomalous Winds

A grass fire on July 15, 1974 west and northwest of the 300 Area provided us with an opportunity to observe and photograph dust devils over an area where the surface albedo and vegetation had been drastically changed from its normal state.

A day after the fire visual observations verified the existence of frequent dust devils. A frequency count and photography were performed on two additional days. On July 24 , visual observations were made and photographs were taken at 200 -West about one-half mile north of U-pond.

The frequency of dust devils of all sizes was approximately 20 per hcur in the grass-fire area. Only three per hour occurred during the one afternoon of observations at 200-West Area.

We plan to continue our observations during the summer and include the results in a report on dust devils.

\section{- $\quad$ Groundwater Management Studies}

Groundwater Model and Data Storage and Retrieval (K. L. Kipp, Resources Systems Section)

All card data from well logs have been transferred to magnetic tape for permanent storage and input to the disk based information retrieval system. Several computer programs used for data retrieval have been converted from the PDP-9 to the PDP-11/45 to utilize the larger disk storage system. 
Seven program planning documents covering the ARHCO research programs were written during the month.

Four topical reports were drafted during the month, these include: 1) The Partially Saturated Transient Flow Model Boundary Conditions and Assumptions; 2) Variable Thickness Transient Groundwater Model Boundary Conditions and Assumptions; 3) The Macro-Micro-Ion Transport Model Boundary Conditions and Assumptions; and 4) The Transmissivity Iterative Routine, Boundary Conditions and Assumptions.

Field Measurements and Monitoring Assistance

(A. E. Reisenauer, Resources Systems Section)

The quarterly tape run for water-level measurements in the Hanford we11s was completed during July.

Moisture content of the lysimeter soils was monitored with the neutron probe on July 9 and 10 and again on July 24 and 25.

Soil-Waste Reactions

(R. J. Serne, Water and Waste Management Section)

Eight samples of B-Plant condensate waste were collected at intervals during the month of June 1974. These were analyzed for Sr-90, Cs-137, total ammonia and $\mathrm{pH}$, after a scan to determine the presence of other gamma emitting isotopes. Also found in the wastes were Sb-125, Co-60, Cs-134, $\mathrm{Ru}-106, \mathrm{Eu}-154, \mathrm{Eu}-155$, and $\mathrm{Ce}-144$ - Pr-144. These data are now being evaluated for inclusion in a topical report of the B-Plant condensate waste soil reactions.

A topical report entitled, "Assumptions, Boundary Conditions and Limitations of the PERCOL Model" was completed and will be distributed in the first week in August. The purpose of this report was to document any additional work or input required to give the PERCOL model universal applicability in terms of Hanford waste solutions and soils.

Miscellaneous

A plotting program was written to plot the data accumulated from the temperature and matrix potential data obtained from the instrumented wells near the lysimeter site. All the data has been keypunched on entry into the computer system and plotting should be completed soon. 


\section{TECHNICAL ASSISTANCE TO THE HANFORD PLANT}

\section{Summary}

Environmental Evaluations

A smal1 temporary increase in airborne particulate radioactivity was observed the last week in June following a foreign weapons test. A temporary increase in shoreline dose-rate at $\mathrm{N}$-Area was reduced following an increased flow of water to the $\mathrm{N}$ crib.

Radiation Standards and Engineering

Efforts are continuing in improving the quality of the calibrations program. One prototype $C P$ has been received in response to a bid request for the new Hanford CPS. 


\section{TECHNICAL ASSISTANCE TO THE HANFORD PLANT}

\section{Environment Evaluations \\ (J. P. Corley, Environmenta? EvaTuations Section)}

The routine river shoreline measurements were about the same as before the flood peak $(0.012-0.014 \mathrm{mR} / \mathrm{hr})$, with the exception of the reach at $\mathrm{N}$ Area. A shoreline dose-rate of $0.14 \mathrm{mR} / \mathrm{hr}$ was reduced to a more normal $0.06 \mathrm{mR} / \mathrm{hr}$ after water flow was increased to the $\mathrm{N}$ Crib.

Special fallout sampling of air, milk, and vegetation, initiated following a foreign nuclear weapons test of June 18, was discontinued on July 3. No positive evidence of any initial regional fallout was observed other than a temporary increase in airborne particulate radioactivity for the period June 23 to 26 . The maximum gross beta measurement on daily samples was $0.56 \mathrm{pCi} / \mathrm{m}^{3}$. For comparison, the general regional level of airborne radioactivity before and after this period was $0.3-0.35 \mathrm{pCi} / \mathrm{m}^{3}$ gross beta. Presence of typical nuclides was confirmed by the Radiological Chemistry Section.

Routine surveys of ground plots, roads and retired waste disposal sites showed no unusual conditions.

Nitrate levels in water at the FFTF site have dropped significantly in the past several months, from a range of $12-15 \mathrm{mg} / 1$ to a range of $2-3 \mathrm{mg} / 1$. This is apparentiy the result of changing the mixture from the wells providing this supply, since nearby wells sampling the water table have shown no significant change.

As part of the major we11 maintenance program accomplishments during the last quarter of $\mathrm{FY}-1974$, all routinely sampled wells with more than two feet of water above the perforations were re-perforated above the water table.

Radiation Standards and Engineering

(J. M. Selby, Radiation Standards and Engineering Section)

Due to complaints by prospective suppliers regarding the short time allowed to provide prototype CP models, a time extension was granted by Purchasing. Originally the technical proposal and prototype instrument were 
due on July 23, 1974. The new submission dates are July 30 for the technical proposal and August 23, 1974 for the prototype instrument. One prototype instrument has been received from Eberline Instrument Corporation.

A battery pack was developed to operate a SAM-2 (Stabilized Assay Meter). This system proved to be superior to the motor generator system that had been used for portable operation.

A table of dose rates at various distances, $k V p$ values and currents was established for each of the $K$-fluorescent sources available at Calibrations.

Measurements of the neutron source strength of all chemical neutron sources at Calibrations has been completed. These measurements were made by intercomparison with PuBe M-1221 through the Precision Lung Counter. The measurements confirm or update values of source strength that are being used in routine neutron flux and dose equivalent calibration exposures. The sources measured range from $1.3 \times 10^{5}$ neutrons/sec to $1.8 \times 10^{8}$ neutrons $/ \mathrm{sec}$. A memo to file has been prepared detailing these data and intercomparison techniques.

Work was started on a program to upgrade and formalize our quality assurance procedures. As a first step in this effort block diagrams were developed which denote the traceable path between NBS and our calibration devices.

\section{(E. H. Phinney, Synoptic Meteorology Section)}

Meteorological services, viz., weather forecasts and observations and climatological services were provided to plant operations and management on a routine basis.

\section{Ju1y 1974}

Type

Production Forecasts:

General Forecasts:

Special Forecasts:

Other Requests:

Publications Distributed:

Number of Calls Processed by Code-A-Phone:

Total Service Actions:
No. Made

62

231

4,196

4,902
\% Reliability

82.2

88.2

94.4 


\begin{tabular}{|c|c|}
\hline $\begin{array}{l}\text { Copy } \\
\text { Number }\end{array}$ & OFF-SITE DISTRIBUTION \\
\hline $1-3$ & $\frac{\text { USAEC, Washington-Division of Production }}{\text { F.P. Baranowski }}$ \\
\hline 4 & $\frac{\text { USAEC Headquarters }}{\text { J. L. Liverman, AGMBER }}$ \\
\hline $5-6$ & Technical Information Center, Oak Ridge $\mathrm{Te}$ \\
\hline 7 & Savannah River AEC Operations Office \\
\hline $8-9$ & $\begin{array}{l}\text { E. I. du Pont de Nemours \& Company } \\
\text { Savannah River Laboratory }\end{array}$ \\
\hline 10 & $\frac{\text { AEC Idaho Operations Office }}{\text { K. K. Kennedy }}$ \\
\hline \multirow[t]{3}{*}{11} & $\frac{\text { Allied Chemical Corporation, Idaho Falls }}{\text { J.A. Buckham }}$ \\
\hline & ON-SITE DISTRIBUTION \\
\hline & AEC Richland Operations Office \\
\hline $\begin{array}{l}12 \\
13 \\
14 \\
15 \\
16 \\
17\end{array}$ & $\begin{array}{l}\text { 0. J. Elgert } \\
\text { A. G. Fremling } \\
\text { P. G. Holsted } \\
\text { B. J. Melton } \\
\text { R. B. St. John } \\
\text { F. R. Standerfer } \\
\text { United Nuclear Industries, Inc. }\end{array}$ \\
\hline $\begin{array}{l}18 \\
19 \\
20 \\
21 \\
22 \\
23 \\
24 \\
25 \\
26\end{array}$ & $\begin{array}{l}\text { P. A. Carlson } \\
\text { C. D. Corbit } \\
\text { R. E. Dunn } \\
\text { A. E. Engler } \\
\text { C. Harrington } \\
\text { R. T. Jessen } \\
\text { A. R. McGuire } \\
\text { N. R. Miller } \\
\text { J. T. Stringer/H. F. Tew } \\
\text { Atlantic Richfield Company }\end{array}$ \\
\hline $\begin{array}{l}27 \\
28 \\
29 \\
30 \\
31 \\
32 \\
33\end{array}$ & $\begin{array}{l}\text { G. E. Backman } \\
\text { G. L. Borsheim } \\
\text { D. J. Brown } \\
\text { L. E. Bruns } \\
\text { M. H. Campbe11 } \\
\text { R. E. Fe1t } \\
\text { R. D. Fox }\end{array}$ \\
\hline
\end{tabular}

Atlantic Richfield Company (cont.)

34 R. G. Geier

35 D. G. Harlow

36 W. M. Harty

37 H. H. Hopkins

38 W. P. Ingalls

39 R. E. Isaacson

$40 \quad H$. Jensen

41 L. M. Knights

42 W. D. Luening

43 C. W. Malody

44 T. R. McKenzie

45 B. J. McMurray

46 G. A. Nichol son

47 G. C. Oberg

48 J. V. Panesko

49 K. R. Price

50 W. W. Schulz

51 H. P. Shaw

52 A. E. Smith

53 R. E. Smith

54 G. T. Stocking

55 M. J. Szulinski

56 W. J. Van Slyke

57 D. D. Wodrich

R. D. Fox 
Number

Westinghouse Hanford Company

58 G. J. Alkire

59 A. G. Blasewitz

Battelle-Northwest

60 R. E. Burns

61 E. D. Clayton

62 J. P. Corley

63 J. R. Eliason

64 R. F. Foster

65 T. R. Garland

66 K. M. Harmon

67 H. L. Henry

68 G. Jansen

69 J. H. Jarrett

70 J. L. McElroy

71 J. E. Minor

72 R. E. Nightingale

73 D. E. Olesen

74 W. D. Richmond

75 W. H. Rickard

76 R. C. Routson

77 L. C. Schwendiman

78 G. A. Sehme 1

79 A. J. Shuckrow

80 C. L. Simpson

81 W. G. N. Slinn

82 R. I. Smith

83 H. H. Van Tuyl

84 B. E. Vaughan

85 D. G. Watson

86 R. E. Wildung

87 R. K. Woodruff

88 J. R. Young

89-91 Technical Information Files 